\title{
An ionic contrast agent inhibits platelet-dependent thrombin generation and boosts the effect of abciximab.
}

Citation for published version (APA):

al Dieri, R., de Muinck, E. D., Hemker, H. C., \& Béguin, S. (2001). An ionic contrast agent inhibits plateletdependent thrombin generation and boosts the effect of abciximab. Thrombosis and Haemostasis, 85, 944-945. https://doi.org/10.1055/s-0037-1615778

Document status and date:

Published: 01/01/2001

DOI:

10.1055/s-0037-1615778

Document Version:

Publisher's PDF, also known as Version of record

Please check the document version of this publication:

- A submitted manuscript is the version of the article upon submission and before peer-review. There can be important differences between the submitted version and the official published version of record.

People interested in the research are advised to contact the author for the final version of the publication, or visit the DOI to the publisher's website.

- The final author version and the galley proof are versions of the publication after peer review.

- The final published version features the final layout of the paper including the volume, issue and page numbers.

Link to publication

\footnotetext{
General rights rights.

- You may freely distribute the URL identifying the publication in the public portal. please follow below link for the End User Agreement:

www.umlib.nl/taverne-license

Take down policy

If you believe that this document breaches copyright please contact us at:

repository@maastrichtuniversity.nl

providing details and we will investigate your claim.
}

Copyright and moral rights for the publications made accessible in the public portal are retained by the authors and/or other copyright owners and it is a condition of accessing publications that users recognise and abide by the legal requirements associated with these

- Users may download and print one copy of any publication from the public portal for the purpose of private study or research.

- You may not further distribute the material or use it for any profit-making activity or commercial gain

If the publication is distributed under the terms of Article $25 \mathrm{fa}$ of the Dutch Copyright Act, indicated by the "Taverne" license above, 
of $119 \%$. In subsequent tests the 40-year-old father (F.E.) and one 5-year-old sister (K.E.) tested heterozygous for the mutation while mother and two other sisters displayed a wild type genotype.

With only three individuals known so far to carry this mutation, assessment of its clinical importance is obviously not possible. It is fair to assume that the mutation 20221 is considerably less frequent than mutation 20210 - at least among Caucasians; our laboratory alone tested 416 samples from patients of this hospital (predominantly Caucasians) using the LightCycler test. 31 of these samples were heterozygous for mutation 20210, while only one sample (O.E.) was heterozygous for the new mutation.

Unfortunately, most of the assays used today for detection of the known prothrombin mutation are based on restriction fragment length polymorphism (RFLP) and will not detect people carrying this new mutation. Thus other carriers of the mutation might have been gone undetected and were diagnosed as wild type on the DNA level. In the past only sequencing or SSCP would have detected the new mutation. The new LightCycler assay is the first convenient assay which can detect both mutations at the same time.

Elevated prothrombin level, early renal transplant rejection and signs of ischemic stroke may have occurred only coincidentally in this patient together with the new mutation, especially since these features can occur in wild type individuals as well. Nevertheless these coincidences are, without question, noteworthy and warrant further investigation in order to elucidate the clinical significance of this new mutation in respect to frequency and distribution in different populations and to assess the thromboembolic risk accompanying this genetic variation.

Mark Wylenzek ${ }^{1}$, Christof Geisen ${ }^{1}$, Ludwig Stapenhorst ${ }^{2}$, Klaus Wielckens $^{1}$, Karl R. Klingler ${ }^{1}$

${ }^{1}$ Institut für Klinische Chemie, Universität zu Köln, Köln, Germany

${ }^{2}$ Klinik und Poliklinik für Allgemeine Kinderheilkunde, Universität zu Köln, Köln, Germany

\section{References}

1. Poort SR, Rosendaal FR, Reitsma PH, Bertina RM. A common genetic variation in the 3'-untranslated region of the prothrombin gene is associated with elevated plasma prothrombin levels and an increase in venous thrombosis. Blood 1996; 88: 3698-703.

2. Oh J, Schaefer F, Veldmann A, Nowak G, Nowak-Gottl U, Tonshoff B, Kreuz W. Heterozygous prothrombin gene mutation: a new risk factor for early renal allograft thrombosis. Transplantation 1999; 68: 575-8.

Received December 28, 2000 Accepted after resubmission January 8, 2001

\section{An Ionic Contrast Agent Inhibits Platelet-dependent Thrombin Generation and Boosts the Effect of Abciximab}

Dear Sir,

Abciximab, administered intravenously during high-risk angioplasty, including angioplasty for refractory unstable angina pectoris, has been shown to significantly reduce acute and subacute closure and the combined end point of death, myocardial infarction and revascularisation (1). This is attributed to the blocking of the GPIIb/IIIa receptor, which inhibits not only platelet aggregation but also thrombin generation (2). In fact thrombin generation in platelet-poor plasma is inhibited by all anticoagulant drugs and in platelet-rich plasma, in addition, by all anti-platelet agents that we investigated (2).

In acute coronary obstruction, radiographic visualization of the coronaries is a routine procedure. It has been reported that contrast agents have an influence on blood coagulation and on thrombus formation and that, in this respect, there is a significant difference between ionic and non-ionic contrast agents (3). We therefore investigated the effect on platelet-mediated thrombin generation of an ionic (ioxaglate) and a non-ionic dimeric contrast agent (iodixanol) with an identical iodine content $(320 \mathrm{mg} / \mathrm{ml})$.

To this end we determined the thrombin concentration in timed subsamples from citrated platelet-rich plasma $(300,000 \mathrm{pl} / \mu \mathrm{l})$ in which thrombin generation had been triggered by recalcification.

Correspondence to: Prof. H. C. Hemker, P.O. Box 616, 6200 MD, University Maastricht, The Netherlands - Tel.: +31-43-3881675, Fax: +31-43-3884159, E-mail: HC.Hemker@thrombin.com.
We observed that both contrast agents, when added to normal platelet rich plasma (PRP) in vitro, had an inhibitory and retarding effect on thrombin generation but the ionic one much more so than the non-ionic one (data not shown). A similar inhibition was seen in PRP from six patients after they had received $25 \mathrm{ml}$ of ioxaglate during the course of a coronary angiographic procedure (data not shown).

In vitro we also observed a significant potentiating effect of the ionic contrast agent on the inhibition of thrombin generation brought

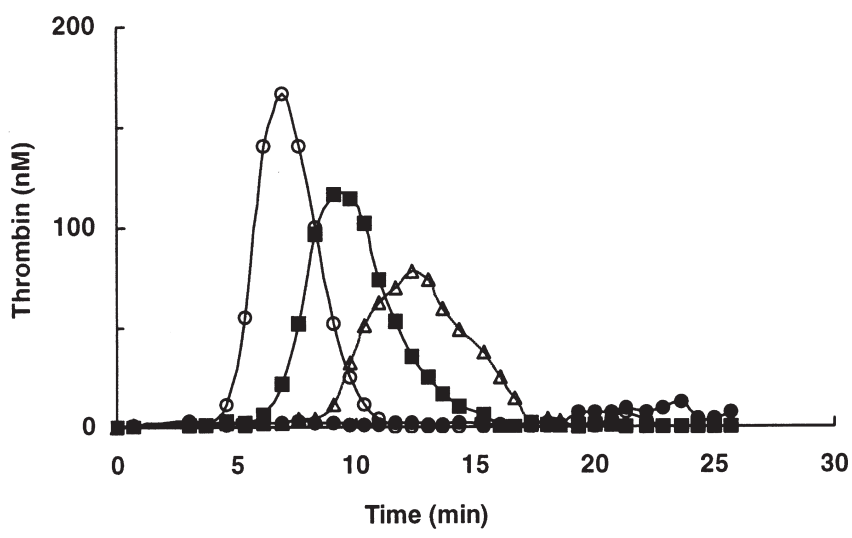

Fig. 1 The effect of ioxaglate on platelet-mediated thrombin generation in the presence of abciximab. $\bigcirc$ : no additions; $\boldsymbol{\square}$ : abciximab $40 \mu \mathrm{g} / \mathrm{ml}$; $\triangle$ ioxaglate $2.5 \%$; abciximab $40 \mu \mathrm{g} / \mathrm{ml}$ and ioxaglate $2.5 \% \mathrm{v} / \mathrm{v}$ 
about by abciximab (Fig. 1) but not of the non-ionic one (data not shown). In contrast, the dose-effect relationship of heparin on the inhibition and retardation of thrombin formation was not significantly different in the presence and in the absence of the contrast agent (data not shown).

We conclude that, upon comparison of the effect on thrombin generation in vitro and ex vivo the ionic contrast agent significantly inhibits platelet-dependent thrombin generation and boosts the effect of abciximab, whereas the non-ionic one does not.

On basis of the ex vivo results reported here one can expect an accessory antithrombotic effect of ionic contrast media. This potentially has important clinical implications. This, however, until now does not appear unequivocally from clinical observations, that tend to remain contradictory $(3,4)$.

Raed Al Dieri, Ebo de Muinck, H. Coenraad Hemker, Suzette Béguin Synapse Laboratories and Department of Cardiology, Cardiovascular Research Institute (CARIM), Universiteit Maastricht, The Netherlands

\section{References}

1. Randomised placebo-controlled trial of abciximab before and during coronary intervention in refractory unstable angina: the CAPTURE study. The Lancet 1997; 349: 1429-35.

2. Béguin S, Kumar R, Keulerts I, Seligsohn U, Coller BS, Hemker HC. Fibrin-dependent platelet procoagulant activity requires GPIb receptors and von Willebrand factor. Blood 1999; 93: 564-70.

3. Grines CL, Schreiber TL, Savas V, Jones DE, Zidar FJ, Ganghadharan V, Brodsk M, Levin R, Safian R, Puchrowicz-Ochocki S, Castellani MD, O'Neill WW. A randomized trial of low osmolar versus non-ionic contrast media in patients with myocardial infarction or unstable angina undergoing percutaneous transluminal coronary angioplasty. J. Am Coll Cardiol 1996; 27: 1381-6.

4. Davidson CJ, Laskey WJ, Hermiller JB, Harrison JK, Matthai W, Vlietstra RE, Brinker JA, Kereiakes DJ, Muhlestein JB, Lansky A, Popma JJ, Buchbinder M, Hirshfeld JW. Randomized trial of contrast media utilisation in high-risk PTCA; the COURT trial. Circulation 2000; 101: 2172-7.

Received December 28, 2000 Accepted after revision January 8, 2001

\section{Avoiding Overanticoagulation: Pharmacogenomics or Pragmatism?}

Dear Sir,

The recent study by Margaglione et al. (1) is an important contribution to a series of studies addressing the potential role of pharmacogenomics in oral anticoagulant therapy (2). In conjunction with the original clinical investigation by Aithal et al. (3), and a recent study from our department (4), it provides unequivocal evidence of a significant effect of the CYP2C9 locus on warfarin sensitivity. However, the findings on bleeding events require specific consideration and, as the authors state, the important question of clinical application remains to be answered.

The initial study by Aithal et al. revealed an association between CYP2C9 variant alleles and warfarin dose requirement. The odds ratios for patients with a maintenenance dose of $1.5 \mathrm{mg}$ or less compared with the general population was 2.68 and with two variant alleles 7.8. In a subsequent study we assessed the influence of variant alleles on warfarin maintenance dose requirement and the risk of overanticoagulation during long-term treatment. We found mean maintenance doses of 5.01, 4.31 and $3.97 \mathrm{mg}$ in wild type homozygotes and $* 2$ and $* 3$ heterozygotes respectively. Margaglione et al. used a factorial ANOVA model to calculate mean maintenance doses of $5.6,4.7$ and $4.0 \mathrm{mg}$ in the same categories of patients. Despite the influence of the CYP2C9 genotype on warfarin sensitivity we did not find an increased incidence of overanticoagulation, as measured by the INR, in patients with variant alleles. This indicated that once a stable anticoagulant effect is established in patients with variant alleles, although their warfarin dose requirements are lower, their responsiveness is stable and they are not

Correspondence to: Trevor Baglin, PhD FRCP FRCPath, Department of Haematology, Addenbrooke's Hospital, Cambridge University Hospitals Trust, Cambridge CB2 2QQ, United Kingdom - Tel.: +44 1223 216748; Fax: +44 1223 217017; E-mail:tpb20@cam.ac.uk more prone to overanticoagulation. In contrast, during initiation of anticoagulation before stability has been achieved, Aithal et al. were able to show that overanticogulation is more likely in patients with variant alleles and they are at increased risk of bleeding. A surprising finding from the latest study by Margaglione et al. is the observed increased incidence of bleeding events in association with variant alleles despite a similar median INR at the time of bleeding to that observed in patients without bleeding. If the bleeding risk associated with the $C Y P 2 C 9$ locus is a pharmacogenomic effect mediated through warfarin metabolism one would expect bleeding events to be related to overanticoagulation as suggested in the original study by Aithal et al. An increased risk of bleeding unrelated to the intensity of anticoagulation achieved is not readily explained. The study also reported an increased incidence of a local bleeding source in patients with variant alleles. At first this finding seems to lack biological plausibility. However, if bleeding risk is truly increased in patients with variant alleles, irrespective of intensity of anticoagulation, then bleeding would be more likely in patients with an occult underlying focal bleeding source and so these patients would be over-represented. Clearly, the finding should not be dismissed and the possibility of an unexpected effect of the CYP2C9 locus on haemostasis, in addition to warfarin sensitivity, should be explored in further studies.

Clinical application now has to be addressed. Clarification of the predictive value of $C Y P 2 C 9$ genotyping is mandatory if genetic testing is to be considered. Whilst not impossible delivery of rapid genotyping on a daily basis would pose considerable logistical problems for many clinical laboratories. Therefore, it is also essential to determine if rigourous application of warfarin loading nomograms will in themselves identify patients with increased warfarin sensitivity. In this respect it is important to note that in an ongoing prospective study we have found that $C Y P 2 C 9$ variant alleles are not the usual explanation for overanticoagulation during initiation of warfarin therapy. With respect to long- 